\title{
ATHENS AND JERUSALEM
}

\author{
God, Humans, and Nature
}

What is the relation of philosophy and theology? This question has been a matter of perennial concern in the history of Western thought. Written by one of the premier philosophers in the areas of Jewish ethics and interfaith issues between Judaism and Christianity, Athens and Jerusalem contends that philosophy and theology are not mutually exclusive.

In this masterful book based on the Gifford Lectures he delivered at the University of Aberdeen in 2017, David Novak explores the commonalities between philosophy and theology on metaphysical, epistemological, and ethical questions. Where are they different and where are they the same? And, how can they speak to one another?

(The Kenneth Michael Tanenbaum Series in Jewish Studies)

DAVID NOVAK is the J. Richard and Dorothy Shiff Chair of Jewish Studies and a professor of Philosophy at the University of Toronto. 


\section{The Kenneth Michael Tanenbaum Series in Jewish Studies}

The Kenneth Michael Tanenbaum Book Series features outstanding research on topics in all areas of Jewish Studies. This interdisciplinary series highlights especially research developed within the framework of the University of Toronto's Centre for Jewish Studies. The Centre is an interdisciplinary research and teaching unit with a large and diverse cohort of affiliated faculty and an impressive roster of annual conferences, symposia, and lectures. Reflecting the Centre's vibrancy, the series highlights the best new research by local and international scholars who contribute to the intellectual life of this interdisciplinary community. The series has been enabled by a generous donation from Kenneth Tanenbaum, whose family has long supported the Centre and helped make it a leader globally in Jewish Studies.

General Editor: Anna Shternshis, Director, Centre for Jewish Studies, Professor of Political Science, University of Toronto

For a list of books in the series, see page 375. 


\section{Athens and Jerusalem \\ God, Humans, and Nature}

The Gifford Lectures 2017

DAVID NOVAK

UNIVERSITY OF TORONTO PRESS

Toronto Buffalo London 
(C) University of Toronto Press 2019

Toronto Buffalo London utorontopress.com

Printed in the U.S.A.

ISBN 978-1-4875-0617-9 (cloth)

ISBN 978-1-4875-2415-9 (paper)

Printed on acid-free paper with vegetable-based inks.

The Kenneth Michael Tanenbaum Series in Jewish Studies

\section{Library and Archives Canada Cataloguing in Publication}

Title: Athens and Jerusalem : God, humans, and nature / David Novak.

Names: Novak, David, 1941- author.

Series: Kenneth Michael Tanenbaum series in Jewish studies.

Description: Series statement: The Kenneth Michael Tanenbaum series in

Jewish studies I Includes bibliographical references and index.

Identifiers: Canadiana 2019013206X I ISBN 9781487524159 (paper) | ISBN

9781487506179 (cloth)

Subjects: LCSH: Philosophy. I LCSH: Theology.

Classification: LCC BL51 .N68 2019 | DDC 261.5/1-dc23

University of Toronto Press acknowledges the financial assistance to its publishing program of the Canada Council for the Arts and the Ontario Arts

Council, an agency of the Government of Ontario.

Canada Council

for the Arts
Conseil des Arts du Canada

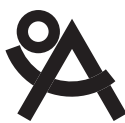

ONTARIO ARTS COUNCIL CONSEIL DES ARTS DE L'ONTARIO

an Ontario government agency un organisme du gouvernement de l'Ontario 
To the memory of my beloved granddaughter Batsheva Stadlan

She obtained favour in the eyes of all who saw her.

(Esther 2:15) 
This page intentionally left blank 